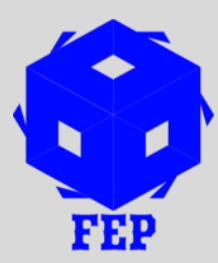

\title{
ETHICAL DILEMMAS OF PRO SOCIAL TELEVISION
}

\author{
${ }^{1}$ Ibrahim T.I. Ukka
}

${ }^{1}$ School of Journalism and Information Communication,

Huazhong University of Science and Technology, 1037 Luoyu Rd. Wuhan 430074, China.

${ }^{2}$ Department of print and electronic journalism, An-Najah National University, Nablus, Palestine

*Corresponding Author: Ibrahim T.I. Ukka

${ }^{1}$ Corresponding Author Email: ibrahimokah@hust.edu.cn

Article Received: 11-07-19 Accepted: 20-08-19

Published: 05-09-19

Licensing Details: Author retains the right of this article. The article is distributed under the terms of the Creative Commons Attribution-NonCommercial 4.0 License

(http://www.creativecommons.org/licences/by-nc/4.0/) which permits non-commercial use, reproduction and distribution of the work without further permission provided the original work is attributed as specified on the Journal open access page.

\section{ABSTRACT}

The use of television to promote social development has generated ethical dilemmas that will affect several billion television viewers during 1990s. Development is defined as a widely participatory process of directed social change in a society, intended to bring about both social and material advancement (Rogers, 1976). Television has a greater potential impact on social development now than ever before in human history. Several countries are systematically producing television programs with pro-social messages. Pro-social television content refers to televised performances that depict cognitive, affective, or behavioral activities considered to be socially desirable by most members of a television audience (Rushton, 1982). Ethical concerns regarding the responsible use of television are prompting television producers and officials to reduce the antisocial effects of television by increasing the pro-social content of television programs.

Keywords: Ethical Dilemmas, Media Effect, Pro-social Television, Communication Ethics

\section{INTRODUCTION}

While the use of pro-social television programs raises several ethical dilemmas (as we will show later in this essay), literature on television ethics is severely limited. Television ethics represents a relatively neglected and undeveloped field of inquiry. Existing research focuses primarily on specialized themes such as television news ethics (Cooper, 1988).

The purpose of the paper is stated as follows:

1. To investigate the use of pro-social television 
2. To review relevant theory on communication ethics,

3. To address several important ethical dilemmas that television producers, educators, government officials, and communication scholars should consider as television's influence grows during the 1990s.

Problem statements of the paper are stated as follows:

1. What is the influence of television's growing?

2. How is the growth of pro-social television?

3. What are ethical dilemmas of pro-social television?

\section{THEORY}

The expanding use of television worldwide for social development raises important ethical concerns that need to be discussed by television producers, government officials, and media scholars. First, we discuss perspectives provided by several key ethical theorists to define and evaluate the ethics of pro-social media. Then we discuss four ethical dilemmas associated with pro-social television.

Aristotle's (1960) "golden men" concept suggest that messages should be tailored to address an audience in the "prime of life", balancing the extreme characteristics of young people and old people. Aristotle emphasized that ethical conduct is attained by actions that are intermediate between extremes, and that moral knowledge and ethics are produced collectively (Johnstone, 1980). Consistent with Aristotle's ethical theory, several media planners have created pro social messages that are addressed to the "golden mean" of modern societies, focusing on the common needs of most people. However, using pro social media to address only these audiences may lead media planners to ignore needs of other demographic groups, especially minorities.

Other media planners have created pro social messages consistent with John Stewart Mill's (1957) "principle of utility", which judges an action to be ethically appropriate only when it produces the greatest amount of good for the greatest number of people in a society (Merrill \& Barney, 1975, p. 11). Creating pro social messages that produce the greatest good for the greatest number of people is difficult to implement because someone must define what constitutes the "greatest good".

Immanuel Kant's (1964) ethic of the "categorical imperative" has also influenced ethical theory in the media. Kant believed that every person should have an equal opportunity to receive beneficial media messages, and that the focus of such messages should be first to help the individuals, not just to change the individuals to achieve a government's objectives.

The ethical view presented in the present article is closely related to Kantian philosophy. We suggest that common human values should be considered in producing pro social media messages. Minnick (1980) noted that Albert Schweitzer defined ethics as nothing more than reverence for life. It implies that moral judgments are built upon commonly accepted values. Ethics emerge from enduring social values rather than from logically defensible propositions. Thus, ethical communication has a dimension of social identity.

We define ethical communication as that which upholds and protects an individual's freedom, equality, dignity and physical and psychological well-being. Communication media are ethically employed when they are not the limiting factor in addressing individual and 
social needs. If the media fail to uphold and protect basic human values, or limit people's access to resources that provide their basic needs, then it is used unethically.

\section{Television's Growing Influence}

\section{DISCUSSION}

The use of communication satellites has rapidly expanded television audience's worldwide. In Third World nations, the percentage of the world's total number of television sets increased from 5 percent in 1965, to 10 percent in 1975, 7020 percent in 1984, and 40 percent in 1988. During the eight year period from 1980 to 1987 , the number of television sets increased by 15 times in the People's Republic of China, and by 10 times in India. Television now reaches 550 million of China's 1.1 billion people (50\%), about 120 million people in India (15\%), and about 70 million people in Mexico (87\%). Sharp increases in the size of television audiences have occurred in other countries.

As television audiences increase, entertainment television is rapidly replacing educational television. Entertainment television is comprised of televised performances intended to capture the interest or attention of individuals, giving them pleasure and/or amusement. Educational television refers to a televised program of instruction and training intended to develop an individual's mental, moral, or physical skills to achieve a particular end. Entertainment programs are highly popular in Third world countries. In India, television began as educational programs. This same trend is occurring in other countries because entertainment programs attract larger audiences, are viewed for longer periods, and generate greater profits than do educational programs.

Despite the sustained growth of entertainment television, little is known about the pro-social effects of entertainment television programs. There are several reasons for this limited knowledge. First, television programs are commonly categorized into a dichotomy that separates entertainment television from educational television. In the past four decades this dichotomy has been reified in the way television and its effects have been discussed and researched. For example, before cable television" and "entertainment television" was often referred to as "commercial television" and "educational television" was called "public television".

These arbitrary labels complicate research on the effects of television programs. Educational programs like Sesame Street can be highly entertaining, and entertaining program like Shogun and The Day After cab be highly educational. The prevailing notion that "entertainment television entertains rather than educates" limits a researcher's framework by underestimating the importance of entertainment television's educational and social influence.

A second reason for the paucity of research on the pro social effects of entertainment television is the emphasis on studying television's antisocial effects. Anti-social is undesirable by most members of a social system. Of the many thousands of studies conducted on anti-social television effects, we identify four major research strains:

\section{The Harmful Effects of Television Violence.}

The effects promoting inaccurate health-related information on television

The portrayal of negative (and often discriminating) images of women and children on television 
The unrealistic depiction of interpersonal and social relationships on television

In contrast, relatively few studies have focused on the pro social effects of intertainment television. Therefore much less is known about the effects television programs that are intended to have positive social impacts than is known about the unintended anti social effects of entertainment television.

\section{The Growth of Pro Social Television}

The idea of producing entertainment television programs for pro-social purposes is not new. However, the use of human communication theories to promote specific pro social beliefs and behaviors through entertainment television programs (not just commercials) is relatively new practice.

Mexico was the first country to develop a theoretical framework for producing pro social television programs. From 1975 to 1981, televise, Mexico's private national television network, produced six series of telenovelas (soap operas) in order to promote adult literacy, family planning, and gender quality. The Mexican soap operas, also called pro-development soap operas, utilized an entertainment education communication strategy to induce cognitive and behavioral changes in their viewers.

On several occasions, U.S television producers have incorporated pro social messages into entertainment television programs. We can know in television mini-series studied, Shogun , positively affected viewer's attitude toward the Japanese; the series increased viewer's knowledge of the Japanese language, history, and customs, and increased their desire to be socially closer to the Japanese people.

Numerous organizations maintain a presence in Hollywood in order to influence U.S television producers to include social issues in an episode of a television series. These "Hollywood lobbyists" (social cause groups) occasionally are successful is getting their issue presented on prime-time television, and thus raise public consciousness about that issue.

Educational institutions also have made contributions to the production of pro social messages. For example: the Harvard University School of Public Health instigated the "designated driver" television campaign to prevent drinking and driving. As social problems facing many countries become more acute, as is expected with the growing AIDS crisis and widespread drug abuse, more pro social television content is likely to be broadcast during the 1990s.

\section{Ethical Dilemmas of Pro Social Television}

An evaluation of pro social television according to our definition of ethical communication has revealed four important ethical dilemmas:

1. The pro social content dilemma, that is, how to distinguish pro social from antisocial television content.

2. The socio-cultural equality dilemma, that is how to ensure that pro social television upholds socio-cultural equality among viewers

3. The unintended effects dilemma, that is how to respond to the unintended consequences of pro social television;

4. The pro social development dilemma, that is, how to respond to those who argue it is unethical to use television as a persuasive tool to guide social development. 


\section{The Pro Social Content Dilemma}

Previously we defined pro social television as televised performances that depict "cognitive, affective, and behavioral activities considered being socially desirable or preferable by most members of a particular social system." Distinguishing pro social content, however, is difficult when people do not have common moral and ethical values. There is some consensus about certain pro social issues in most societies. For example, almost everyone would agree that child abuse is wrong, that violence against women should be stopped, and that it is good to "say no" to illegal drugs. However, the best ways to prevent the abuse of women and children or to prevent drug abuse are hotly disputed, and a lack of consensus exists regarding many social issues.

During the past two decades one of the most controversial social issues in the U.S. has been abortion. In a 1972 episode of Maude, the middle-aged star of the television series decided to get an abortion rather than bear an unwanted child. This episode set off a controversy with right-to-life organizations in the U.S., who demanded equal television attention to their position on abortion. In 1985, an episode of Cagney and Lacey showed a right-to-life group picketing an abortion clinic, causing tremendous concentration among pro-abortion groups in the U.S. For those favoring abortion, the Maude episode was considered to be antisocial (based on the right to life of an unborn child). Similarly, picketing the advocates. Ted Turner, an outspoken abortion-right advocate, invigorated this controversy one again when he recently broadcast Abortion: For Survival on his TBS network. Turner's opponents want equal time on TBS.

At the heart of the pro social content dilemmas is determining "who will decide for whom, what is pro social and what is not". In most Third World nations, including the ones broadcasting pro social television programs, the government overseeing the media usually decides what is pro social. History reveals horrendous abuses by governments who have used the media to promote antisocial beliefs and behaviors, leading many countries governments have used the media ethically and responsibly for pro social purposes.

Unfortunately, the assurance that the media will be used for pro social purposes is not greater in nations where the responsibility for pro social media is left to television producers and commercial advertisers. Such a responsibility shift creates problem for television producers and advertisement. While entertainment television programs depict numerous sexual behaviors every day in U.S., the depiction want to reduce teenage pregnancy and the AIDS epidemic, the networks policy on condom advertising exists because people disagree about the consequences of making condom is virtually nonexistent. Although Americans want to reduce advertising exists because people disagree about the consequences of making condoms the answer to these problems.

The reconciliation of pro social programming in free market economies like the U.S (where television system are commercially driven) is in itself an ethical dilemma. The ongoing contention against commercial television's depiction of tobacco and alcohol use in the U.S illustrates the difficulties encountered when judging the pro social and anti-social content of media messages. Many Americans feel that they should have the freedom decide whether or not to use alcohol and tobacco products, and that restricting information regarding the use of such products is wrong. However, others feel that it is unethical to promote products that encourage potentially harmful beliefs and behaviors. 
The pro social content ethical dilemma results from differing views about what beliefs and behaviors benefit society and which ones are detrimental. Regulation of television content as is often the case in Third World countries is vehemently resisted in the U.S. yet if the decision about pro social television content is left to commercial networks, some of the most important pro social messages may never reach millions of American television viewers. Balancing the freedom of the broadcast media with the need for more pro social television is an ethical dilemma every nation must face.

\section{The Socio-Cultural Equality Dilemma}

A second ethical dilemma in using pro social television concerns the problem of ensuring socio-cultural equality that is, providing an equal treatment on television of various social and cultural groups. Socio-cultural equality means regarding each social and cultural group with the same value or importance. In nations, with a high homogeneity index, a measure of a country's socio - cultural diversity, there is a high degree of consensus regarding a society's normative beliefs and behaviors. In Japan, where the homogeneity index is 50 percent.

Ensuring socio-cultural equality through pro social television is especially important and problematic. In socio - culturally diverse countries, for example, India. The popular Indian television soap opera, hum Log, attacked the dowry system of marriage and challenged traditional beliefs about women's status in Indian society. Research on the effects of Hum Log indicated that ethnicity, geographical residence, gender, and Hindi language fluency of Hum Log viewers were significant determinants of beliefs about gender equality. The subservience of women is considered to be socially and culturally appropriate by many Indians, but not by all. So television's treatment of all viewers as socio-culturally "equal" in India is an ethical dilemma.

The socio - cultural equality dilemma is heightened when pro social television programs are exported to other countries. Television programs are imbued with the socio-cultural values of the society where they are produced. The threat of "cultural imperialism" generates great concern about the socio-cultural impact of imported television programs. For example, the influence of Western entertainment television programs was one factor that contributed to the Iranian revolution. Disdain for the "immoral" sexual relations depicted by several Americanproduced dramatic television serials fueled the Iranian fundamentalist movement against Westernized secularism.

It is difficult to predict that certain viewers may be offended by a television program, even if the program is considered to be pro social. After the Iranian revolution, Iran was careful to only allow broadcasts of programs considered to be "pro-social" in the Islamic sense. A very popular Japanese soap opera, Oshin (a Japanese name), was imported into Iran and dubbed in Farsi (the lingua franca of Iran) because its values did not conflict with Islamic values and the program was a non-Western production. Oshin became so popular in Iran that Teheran traffic fell to a minimum while the program was broadcast. The heroine of the series, Oshin, poor laundry women, achieved dignity and social success through her hard work and determination. Oshin became so well-liked by Iranians that some women began naming their newborn daughters Oshin.

When the Ayatollah Khomeini heard that an Iranian woman on a radio talk show had admitted that Oshin was a more important role model to her than Fatemah Zahra, the Propet Muhammad's daughter, he punished the Director of Iran's broadcasting agency with 50 
lashes. Iran's radio officials had little idea that allowing discussions about the morally acceptable soap opera Oshin would eventually prove disastrous.

\section{The Unintended Effects dilemma}

A third ethical dilemma brought about by the use of pro-social television is the problem of unintended effects. Social development is a complex phenomenon whose consequences are not easily predictable. Undesirable and unintended consequences can result from the diffusion of pro social messages, as officials in Iran discovered. Reluctance to depict condom use on U.S television, as mentioned earlier, demonstrates how a fear of unintended consequences can discourage broadcasts of pro social countries. Many parents fear that television content intended to encourage sexual responsibility might encourage sexual promiscuity instead (Syahputra, 2006).

As evidence by the thousands studies on anti-social television effects, unintended consequences of entertainment television programs are common. To illustrate this problem worldwide, the present discussion will focus on four popular television series: Miami Vice and All in the family, Ven Conmigo, Hum log. Of these series, Ven Conmigoand Hum Log were overtly pro social, All in theo be either family was intended to be somewhat pro social, and Miami Vice was not intended to be either pro social or antisocial (Syahputra, 2006: 43).

In the early 1970s, CBS broadcast a mildly pro social an highly acclaimed situation comedy, All in the Family. The series focused on ethic prejudices through the depiction of a highly bigoted character, Archie Bunker. While the program attempted to point out to viewers the absurdities of their own ethic prejudices, some already-prejudiced viewers became even more prejudiced in their beliefs. Similar finding resulted from studies on the impact of the television mini-series. Viewers of these two television series became more aware o racial issues, but did not become less prejudiced Shoemaker, 1996: 40-45).

NBC's popular crime-drama series, Miami Vice, illustrate that even seemingly insignificant events in entertainment programs may lead to sizable unintended behavioral effects in television viewers. U.S gun shop owners noticed a remarkable effect on the gun-buying behaviors of Miami Vice viewers during the 1980s. Shortly after Detective Sonny Crockett began sporting a shark-gray Australian-made 5,56 mm. Steyr AUG, a semiautomatic assault rifle, on episodes of Miami Vice, gun shops across the U. S were flooded with customer calls asking how they could buy one. Although Miami Vice's producers never claimed they were trying to promote social responsibility NBC was likely surprised to learn the degree to which Miami Vice promoted gun sales and had become the fashion leader in assault weaponry in the U.S (Syaputra, 2006: 65-66).

The third example of an entertainment television program's unintended effects resulted from broadcasts of Ven Conmigo, a Mexican pro social television series that promoted adult literacy. In 1976, an episode of Ven Conmigo announced the location of a government warehouse in Mexico City where free literacy booklets were available. However, Mexican officials greatly underestimated the pro social effects of this episode. Request for literacy booklets far exceeded the warehouse supply, resulting in mass frustration and huge traffic jams near the warehouse in Mexico City.

The pro social In Indian television soap opera, Hum Log also had some unintended effects. Bhagwanti, the mother in the Hum Log family, was supposed to be a negative role model for 
female equality: a subservient, self-sacrificing traditional Indian woman who endured great abuse and hardship, especially from her male chauvinist husband. However, a national survey of Hum Log viewers indicated 80 percent of the viewers who chose Bhagwanti as a positive role model were women. As with the character Archie Bunker, Bhagwanti became a positive role model for viewers (Syahputra, 2006: 66-67).

Another unintended effect of Hum Log was the commercialization of Indian television and the proliferation of other dramatic serials sponsored by advertisers. The profit generated by the program demonstrated that pro social television programs can be commercially successful. However, many Indians believe the commercialization of Indian television will broaden the communication gap between the information-rich and the information -poor and create frustration among disadvantaged viewers who are unable to purchase the advertised consumer goods.

These four examples of unintended consequences from All in the family, Miami Vice, Ven Conmigo, and Hum Log demonstrate how entertainment (and often pro social) televisions programs can produce powerful unintended effects (Sumiaty, 2006: 29).

\section{The Pro-Social Development Dilemma}

Even if a society agrees on set of pro-social beliefs and practices, can maintain a reasonable degree of socio-cultural equality, and can control unintended effects of pro-social television, is it ethical to systematically attempt to use television as a persuasive tool to guide social development or not (Syaputra, 2006: 65-66).

Past research on television effects indicates that we should be concerned about the antisocial effects of television. Thoman (1989) notes that the popular myth describing entertainment television as "mindless entertainment" perpetuates the idea that entertainment programs have little impact on viewer's beliefs and behaviors. It is virtually impossible to produce "valuefree" or "socially innocuous" entertainment programs.

The idea that persuasive communication is unethical and, therefore, should be avoided in television production denies the reality of what past research indicates. Television persuades people: how much, is debatable. Even if 1 percent of a population is persuaded to change a belief or behavior on account of watching television, that is still an important change. Persuasive communication cannot and should not be eliminated in a democratic society. Therefore, arguing that it is unethical to use television to promote pro social beliefs and behaviors seems unreasonable and inconsistent with democratic freedoms. (Sumiaty, 2006: 29).

However, unequivocal promotion of pro social for social development can also represent an untenable ethical position. When there is disagreement about the "rightness" or "wrongness" of certain social beliefs and behaviors, it becomes obvious that what is considered to be "pro social" by any group of people, whether or not it is ethical to produce pro social television depends on a number of factors, including the nature of the belief or behavior being promoted, who decides the pro social status of a certain belief or behavior, and what effects the promotion of a certain belief or behavior are likely to have on an audience. Thus, the ethics of using television as a persuasive tool for social development is inextricably intertwined with the three other ethical dilemmas that were discussed earlier ( Mc Quail, $2000: 18)$. 


\section{CONCLUSION}

In briefly words, we can say that there are four ethical dilemmas associated with the use of pro social television:

1. The ethics of distinguishing pro social and anti-social content in television programs,

2. The ethics of ensuring socio - cultural equality in pro social programs,

3. The ethics of dealing with the unintended effects of pro social television

4. The ethics of using television as a tool to guide social developments.

As television audiences expand in third world countries, and as the number of pro social programs increase, an understanding of these ethical dilemmas becomes crucially important. Promoting pro social change through television requires responsible communication which demands a commitment to the moral responsibility of protecting the public. Since television is already used as a persuasive tool, the ethical use of television calls for the provision of accurate, timely, and freely distributed information that protects the voluntary choices of television viewers.

Entertainment television has a complex social impact in its viewers. If societies are to use television for social development, then the production of pro social television content should not be discouraged, despite the ethical dilemmas associated with its effects. Television consumers who are unhappy with the anti-social effects of entertainment television should become more actively involved in determining the kind of content they desire.

Pro social television can improve the quality of our lives, but if we are to encourage its use, then the responsibility for television content cannot remain on the shoulders of commercial sponsors and networks prone to avoid pro social programming content, or on government officials who can arbitrarily decide what is pro social and what is not. The ethical use of media must be based upon the imperative of protecting our freedom, equality, dignity, and physical and psychological well-bring. In the case of pro social television, ultimately, the ethical dilemmas will be decided by television viewers.

\section{References}

Aristotle. (1960). The rhetoric of Aristote (L. Cooper, Trans.). New York

Cooper, T. W. (1988). Ethisc, journalism and television: Bibliographic constellations, black holes. Journalism Quarterly, 65(2), 450-455, 496.

Denis, M. (2000). Theory of Mass Communication An Introduction to Third Edition. Jakarta: Erlangga Publisher.

Iswandi, S. (2006). Infotainment Journalism: The new arena of Journalism in the Television Industry. Yogyakarta: Pilar Med

Junaedi, D. (2004). Ethics of Journalism Exposing Private Areas in Infotainment. $\mathrm{http} / / \mathrm{wwwsctv} . c o . i \mathrm{~d} / \mathrm{community} /$ archieve/index.php/t-1280html

Kant, I. (1964). Groundwork of the metaphysics of morals (H.J Paton, Trans). New York: Harper Torchbooks.

Magnis, S.F.. (1993). Basic Ethics. Yogakarta: Kanisius.

Mill, J. S. (1957). Utilitarianism. New York: Liberal Arts Press, Bobbs-Merrill. 
Noneng, S. (2006). Abandonment of Journalistic Ethics in Infotainment. Observation. Suing Infotainment. 4(2).. Bandung: BP2i, 2006.

Pamela, S. (1996). Mediating the Message: Theories of Influences on Mass Media Content. New York: Longman, 1996.

Rogers, E. M. (1976). Communication and Development: Critical perspectives (pp.121-133). Newbury Park, CA: Sage.

Rushton, J. P. (1982). Television and pro social behavior. In D. Pearl, L. Bouthilet \& J. Lazar (Eds.), Television \& behavior. Ten years of scientific progress and implications for the eighties (Vol. 2, pp. 248-258). MD:National Institute of Mental Health. 